\title{
Analysis of Three-Dimensional Protein Structure of CBAVD in Indonesia as a Basis for Immunotherapy to Ensure Maternal Health
}

\author{
Maslichah Mafruchati ${ }^{1, *}$, Jonathan Makuwira²
}

\section{Maslichah Mafruchati ${ }^{1, *}$,} Jonathan Makuwira ${ }^{2}$

'Department of Veterinary Anatomy, Faculty of Veterinary Medicine (60115), Universitas Airlangga, Mulyorejo, C Campus, Surabaya, INDONESIA.

${ }^{2}$ Malawi University of Science and Technology, P.O Box 5196, Limbe, MALAWI.

\section{Correspondence}

\section{Maslichah Mafruchati}

Department of Veterinary Anatomy, Faculty of Veterinary Medicine (60115), Universitas Airlangga, Mulyorejo, C Campus, Surabaya, INDONESIA.

E-mail: maslichah-m@fkh.unair.ac.id

History

- Submission Date: 24-05-2021.

- Review completed: 21-06-2021;

- Accepted Date: 02-07-2021.

DOI : 10.5530/pj.2021.13.162

Article Available online

http://www.phcogj.com/v13/i5

Copyright

(C) 2021 Phcogj.Com. This is an openaccess article distributed under the terms of the Creative Commons Attribution 4.0 International license.

\begin{abstract}
Introduction: Congenital Bilateral Advance Vass Deferens (CBAVD) is a birth defect characterized by azoospermia. Determine the protein structure by laboratory research was relatively difficult. The threedimensional structure of proteins is computationally analyzed as an excellent and cost-effective alternative to analyzing protein characteristics. Objective: This study has an objective to identify the three-dimensional protein structure of CBAVD in Indonesia so that it can be used to obtain drugs and immunotherapy. Method: This study uses method of DNA extraction, PCR, and sequencing in collecting the data sample. The data was analyzed using using expasy software and Swiss prot. Result: The results of this study were found 6 CBAVD proteins, four to three dimensional CBAVD protein structures and 2 CBAVD proteins that have not been identified by the three dimensional protein structure. Further studies of CBAVD protein are needed, especially those related to protein isolation and crystallography. Conclusion: The three dimensional protein can be used as immunotherapy to ensure the maternal health.

Key words: CBAVD, Dimensional structure, Maternal health, Protein.
\end{abstract}

\section{INTRODUCTION}

Birth defects (congenital defects or congenital conditions) are disorders that appear at birth and can cause physical or mental disability or death. Birth defects can generally be detected in the prenatal period. However, if this is not detected in the prenatal period, it can be seen from the post-natal examination. However, there are also birth defects that are not detected until childhood and even into adulthood. Congenital Bilateral Advance Vass Deferens (CBAVD) is a birth defect characterized by azoospermia. The incidence of CBAVD is indeed very small, around $2-10 \%$. However, if it is not handled, it will lead to problems, especially the integrity of a household. Infertility characterized by azoospermia can be corrected through surgical and non-surgical procedures. However, surgery still requires experience and further research. In addition, there are many birth defects that cannot be treated or die at an early age ${ }^{1}$.

Birth defects that cause mental disorders will persist throughout life. These birth defects can have an impact on structural, functional or metabolic abnormalities ${ }^{2}$. Each year an estimated 7.9 million children worldwide (approximately 6\% of all births in the world) are born with serious birth defects resulting from genetic disorders or other post-conception causes such as alcohol, rubella, syphilis, deficiency Development of research on CBAVD at the international level has been started since 1968, with the discovery of an American man who died due to an enlarged abscess in the scrotum and the formation of cystic fibrosis that has metastasized various organs, mainly: pancreas, lungs, liver, which allegedly died in connection with immunodeficiency ${ }^{3}$.

Knowledge and understanding of protein structure was very important because it can provide important information in understanding the biochemical properties and functions of these proteins at the molecular level in detail. Determine the protein structure on the laboratory research was relatively difficult because it requires sophisticated instrumentation, long research time and requires a large amount of money ${ }^{4}$. The three-dimensional structure of proteins is computationally analyzed as an excellent and cost-effective alternative in analyzing protein characteristics. Prediction of three-dimensional structures is carried out by means of a homology approach ${ }^{5}$, which is the best choice for determining the three-dimensional structure of proteins by searching for similar sequences in the database as a template. Research purpose of this study is identify the three-dimensional protein structure of CBAVD in Indonesia so that it can be used to obtain drugs and immunotherapy.

\section{MATERIAL AND METHOD}

\section{DNA extraction}

PBMC culture cells with $10^{3}$ cells in $200 \mu \mathrm{l}$ buffer B3 (a mixture of B1 (containing Guanidine hydrochloride) and B2) were incubated for 10-15 minutes at $70^{\circ} \mathrm{C}$. the next step is adding $96 \%$ ethanol with volume $210 \mu \mathrm{l}$ and vortex it. The next step is bind DNA, the mixture is put into the column then centrifuged $11,000 \mathrm{~g}$ for 1 minute. Then the liquid below is removed and washed 2 times, namely the first by adding $500 \mu \mathrm{l}$ of buffer BW (Guanidine hydrochloride and isoprotenol<25\%) then centrifuged $11,000 \mathrm{~g}$ for 1 minute then discarded ${ }^{6}$. Then for the second wash by adding $600 \mu$ of buffer $\mathrm{B} 5$, centrifuged $11,000 \mathrm{~g}$ for 1 minute, liquid on the collecting tube was discarded, centrifuge $11,000 \mathrm{~g}$ for 1 minute to clean ethanol. Put in Colum to $1.5 \mathrm{ml}$ eppendorf tube, add $100 \mu \mathrm{l}$ buffer of elution that has been warmed at $70^{\circ} \mathrm{C}$ and incubated for 1 minute, then $11,000 \mathrm{~g}$ is centrifuged for 1 minute ${ }^{7}$. The 

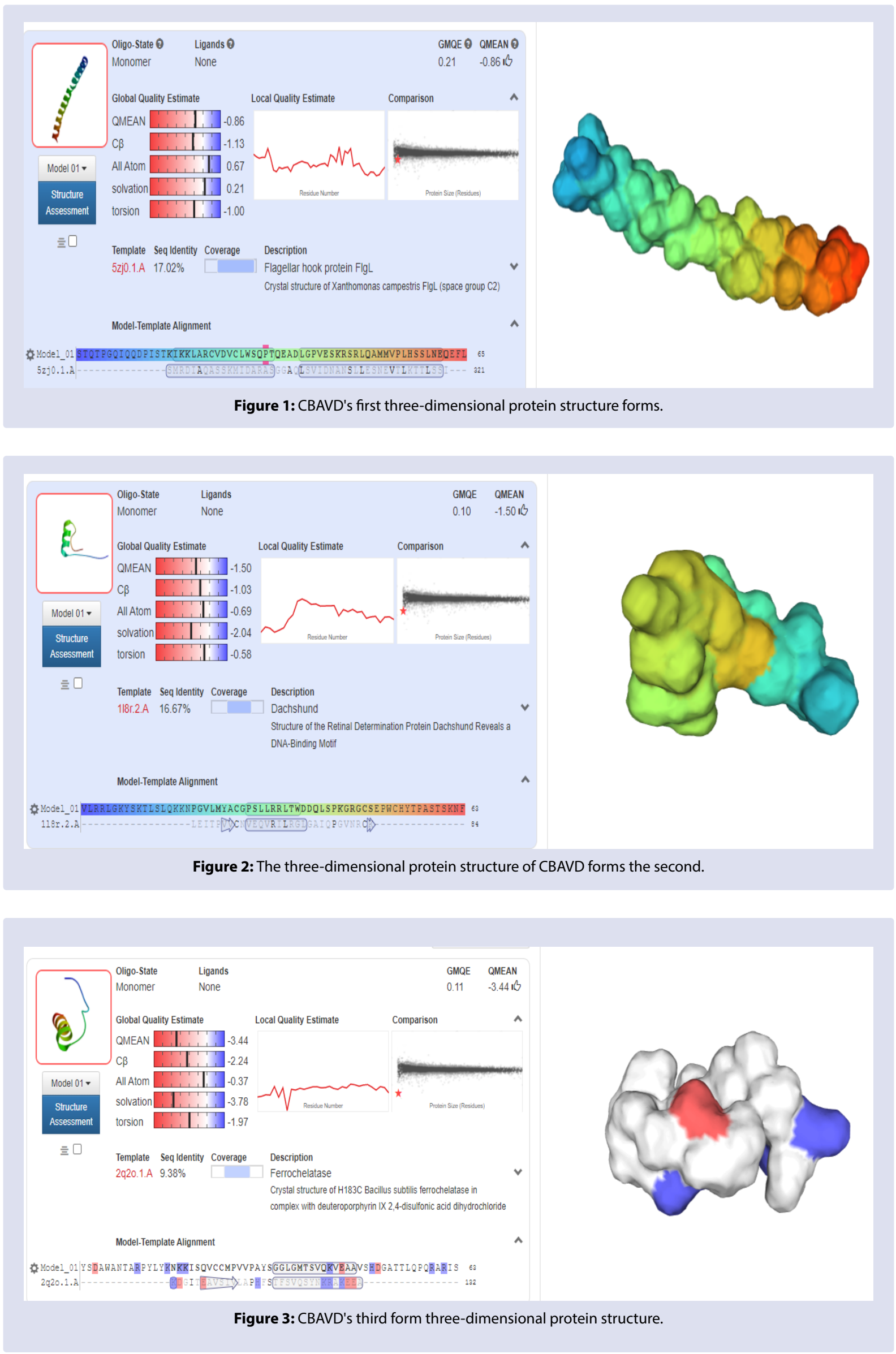

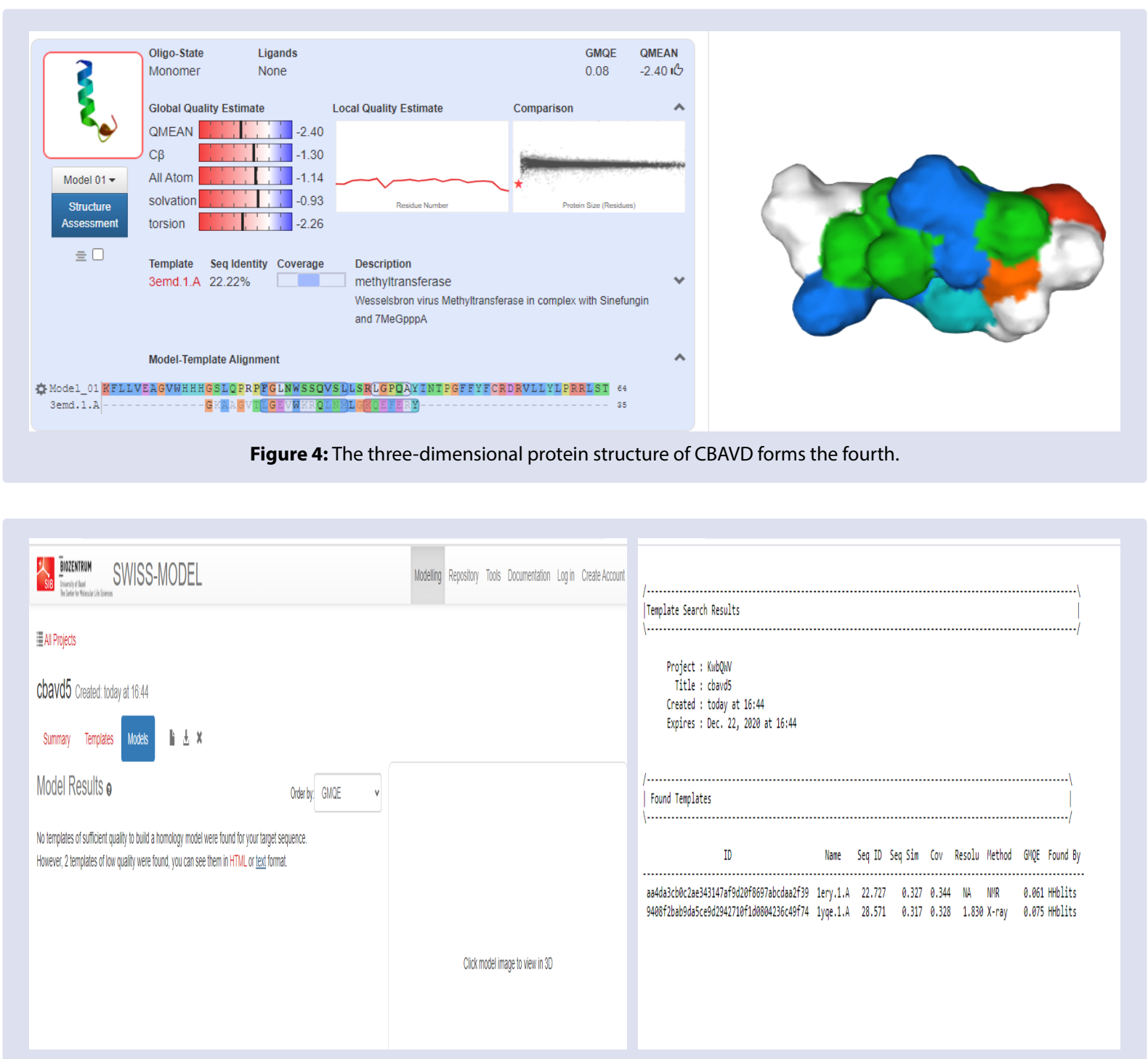

Figure 5: The results of the analysis of the fifth CBAVD three-dimensional protein structure.

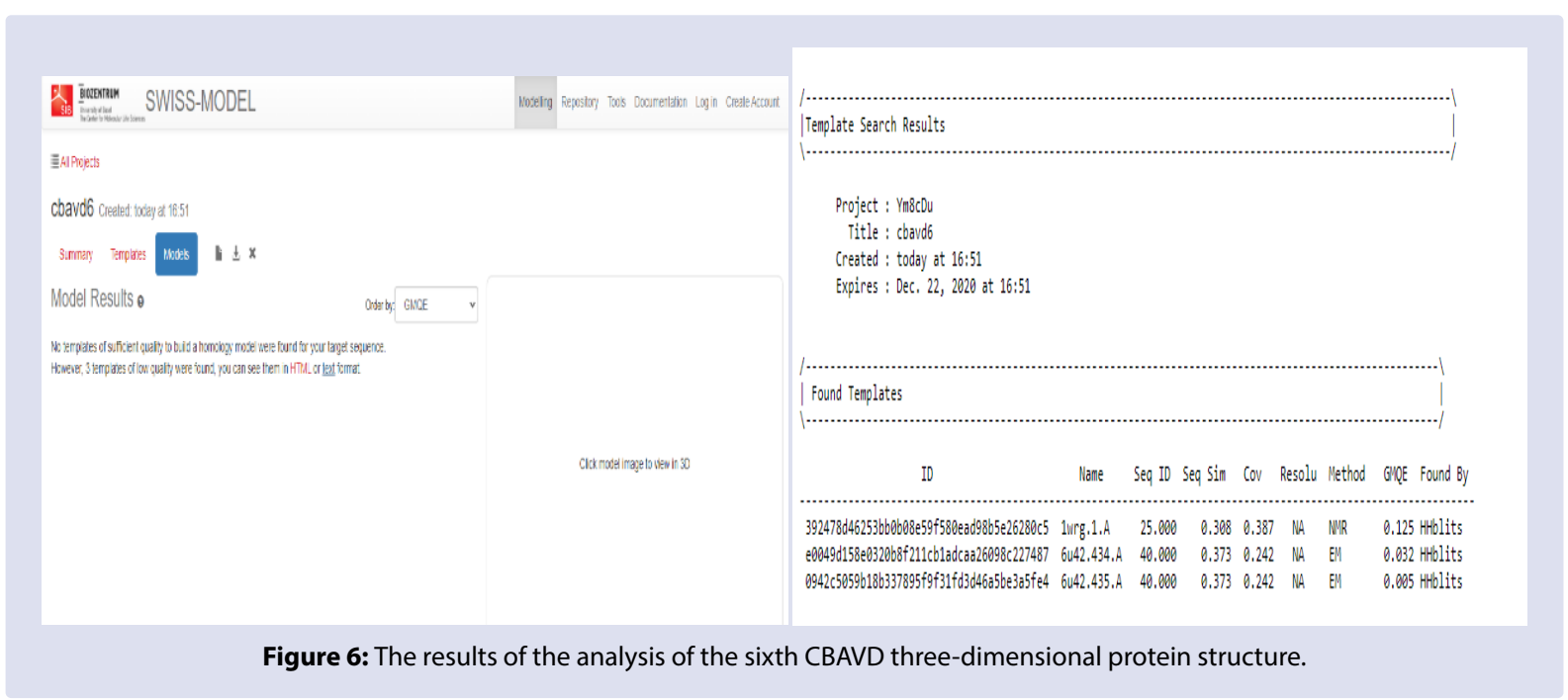


Table 1: Composition of CFRT Gene Primary Outher primers.

$\begin{array}{ll}\text { Primer } & \begin{array}{l}\text { Primer nucleotide arrangement } \\ \text { (Outher Primer Gene CFRT) }\end{array} \\ \text { FORWARD } & \text { CGAGAGACCATGCAGAGGTC } \\ \text { RESERVE } & \text { GCTCCAAGAGAGTCATACCA }\end{array}$

Table 2: Composition of CFRT Inner Primer Gene primers.

\begin{tabular}{ll}
\hline Primer & $\begin{array}{l}\text { Primer nucleotide arrangement } \\
\text { (Inner Primer Gene CFRT) }\end{array}$ \\
\hline FORWARD & CGAGAGACCATGCAGAGGTC \\
RESERVE & TGTACTGCTTTGGTGACTTCCCC
\end{tabular}

Table 3: CBAVD nucleotides translated to proteins.

\begin{tabular}{|c|c|}
\hline CBAVD nucleotides & CBAVD protein \\
\hline \multirow{6}{*}{$\begin{array}{l}\text { AGTACTCAGAC- } \\
\text { GCCTGGGCAAATACAG- } \\
\text { CAAGACCCTATCTCTA- } \\
\text { CAAAAATAAAAAAATTAGCCAG- } \\
\text { GTGTGTTGATGTATGCCTGTG- } \\
\text { GTCCCAGCCTACTCAGGAG- } \\
\text { GCTGACTTGGGATGACCAGTT- } \\
\text { GAGTCCAAAAGGTCGAGGCTG- } \\
\text { CAGTGAGCCATGATGGTGCCAC- } \\
\text { TACACTCCAGCCTCAACGAG- } \\
\text { CAAGAATTTCTA }\end{array}$} & $\begin{array}{l}\text { STQTPGQIQQDPISTKIKKLARCVD- } \\
\text { VCLWSQPTQEADLGPVESKRSR- } \\
\text { LQAMMVPLHSSLNEQEFL }\end{array}$ \\
\hline & $\begin{array}{l}\text { VLRRLGKYSKTLSLQKKNPGVLMY- } \\
\text { ACGPSLLRRLTWDDQLSPKGRGC- } \\
\text { SEPWCHYTPASTSKNF }\end{array}$ \\
\hline & $\begin{array}{l}\text { YSDAWANTARPYLYKNK- } \\
\text { KISQVCCMPVVPAYSGGLGMTS- } \\
\text { VQKVEAAVSHDGATTLQPQRARIS }\end{array}$ \\
\hline & $\begin{array}{l}\text { KFLLVEAGVWHHHGSLQPRPFGL- } \\
\text { NWSSQVSLLSRLGPQAYINTPGFFY- } \\
\text { FCRDRVLLYLPRLST }\end{array}$ \\
\hline & $\begin{array}{l}\text { RNSCSLRLECSGTIMAHCSLDLLD- } \\
\text { STGHPKSASVGWDHRHTSTH- } \\
\text { LANFFIFVEIGSCCICPGVV }\end{array}$ \\
\hline & $\begin{array}{l}\text { EILARGWSVVAPSWLTAASTF- } \\
\text { WTQLVIPSQPPEAGTTGIHQHT- } \\
\text { WLIFLFLRGLAVFAQASEY }\end{array}$ \\
\hline
\end{tabular}

nucleotide base strands for the primer duplicated at this stage are as shown in the table below:

$15 \mu \mathrm{l}$ of PCR products added EDTA, sodium acetate and absolute ethanol, vortex and incubated at $4^{\circ} \mathrm{C}$. The sample stored in a refrigerator at a temperature $\left(-20^{\circ} \mathrm{C}\right)$. The tool used is the ABI 3110 $\mathrm{XL}$ Capillary Sequencer ${ }^{8}$. The sequencing results in the form of a nucleotide sequence were translated into proteins using the Expasy software ${ }^{9}$. Three-dimensional structure analysis using Swiss $\operatorname{Prot}^{10}$.

\section{RESULT AND DISCUSSION}

The results showed that six types of protein were translated from CBAVD nucleotides using Expasy Software. In addition, using the Swiss Prot software, it was found that 4 protein structures of CBAVD and 2 proteins did not have a three-dimensional protein structure. This is because the two proteins have no resemblance to the proteins in the protein database, so it requires further study of the two proteins.

Identify protein structures is faster than research in determining the structure of three-dimensional proteins, so that ideas or ideas are obtained to predict the three-dimensional structure of proteins from existing protein sequences based on known protein sequence data in the laboratory ${ }^{11}$. This is based on the number of protein groups or sequences so that they have a similar structure between the two proteins and conclusions are drawn from the similarity of their sequence. This analysis technique is known as protein modeling and is one of the branches of science in the field of bioinformatics ${ }^{12}$.

In protein modeling, there are protein structures consisting of primary, secondary, tertiary and quaternary structures. The primary structure is the simplest structure with a linear sequence of amino acids and no chain branching. The secondary structure is a two-dimensional protein structure which is a combination of primary structures stabilized linearly by hydrogen bonds between the $=\mathrm{CO}$ and $=\mathrm{NH}$ groups along the polypeptide backbone ${ }^{13}$.

The tertiary structure of a protein is a protein structure on top of a secondary structure consisting of irregular bonds between $\mathrm{R}$ groups of various amino acids. The tertiary structure of a protein is a threedimensional conformation that focuses on the bonds between secondary structures ${ }^{14}$. The three-dimensional structural modeling of proteins consists of the homology/comparative method, the fold recognition method and the ab initio method ${ }^{15}$.

Three-dimensional structural modeling using homology modeling is a three-dimensional protein structure modeling based on the alignment of the target protein's amino acid sequence with similar proteins whose three-dimensional structure is known protein modeling with the homology method is also faster than other methods ${ }^{15}$. The ab initio method is the most difficult and complex method compared to other methods and requires a long processing time, modeling the three-dimensional structure of proteins based on energy functions can only be used in a limited manner for relatively small proteins and the resulting accuracy is also small ${ }^{16}$.

The folding recognition modeling technique is more difficult than homology ${ }^{15}$. The principle of modeling with the fold recognition method is to compare the target sequence with the template structure in the protein database to produce a structure model with the best fold value. Therefore, among the three three-dimensional structural modeling techniques, it can be concluded that the homology modeling method is the best choice method for building three-dimensional protein structure models in silico. Homology modeling is also widely used in virtual screening, mutagenesis experimental design and studying the effects of sequence variation ${ }^{17}$.

In three-dimensional structural modeling, evaluation of the protein structure model is an important stage in modeling. The percentage value of the sequence identity between the target and template is a determinant of the quality of the model. The greater the percentage of identity values between the sequence and the target, the closer the model will be to the original ${ }^{18}$.

Based on three-dimensional structural modeling using swiss model software, CBAVD 1 to 4 proteins have the same $9 \%$ to 22 percent. There were no similarities between CBAVD 5 and CBAVD 6 proteins in the database, so that further research is needed, especially protein isolation and protein crystallography. The results of protein modeling can vary widely and are determined by the level of homology of the target template alignment, the quality of the template, the flexibility of the structure and the software used ${ }^{17}$.

QMEAN (Qualitative Model Energy Analysis) combines several assessment functions to estimate model quality. The two pseudo-energy assessments provided by QMEAN are the Raw Score and the Z-score. The raw score shows the pseudo-energy value calculated statistically from several parameters ${ }^{3}$.

The $\mathrm{Z}$-score value is obtained from the experimental determination of the structure of the same size in X-ray crystallography. The smaller the pseudo-energy value in the raw score, the better, while the bigger the Z-Score the better. From the research results, it was found that the mean $\mathrm{Q}$ value for CBAVD protein $1,2,3$, and $4:-0.86 ;-1.50 ;-3.44 ;-2.40$. For CBAVD 5 and CBAVD 6 proteins, the $Q$ mean value was not obtained ${ }^{19}$.

\section{CONCLUSION}

From the results of the study, it was found that 4 three-dimensional structures of CBAVD protein and 2 CBAVD proteins had not been found so that the protein structure required further study. 


\section{ACKNOWLEDGEMENT}

The author has been checked this paper by turnitin and it was free from plagiarism and never been submitted elsewhere. The author give many thanks for Nidhom Foundation in conducting the data research as well as in providing digital facility to finish the writing process of this paper.

\section{REFERENCES}

1. Samli, H, Samli, M M, Solak, M and Imirzalioglu, N (2006) 'Genetic anomalies detected in patients with non-obstructive azoospermia and oligozoospermia'. Archives of andrology, 52(4), pp. 263-267.

2. Gooren, L J and Giltay, E J (2014) 'Men and women, so different, so similar: observations from cross-sex hormone treatment of transsexual subjects'. Andrologia, 46(5), pp. 570-575.

3. Lin, Chun-Hsuan and Huang, Tsung-Yi (2020) 'Congenital bilateral absence of the vas deferens (CBAVD) with bilaterally present seminal vesicles'. Urology Case Reports, p. 101131.

4. Senior, Andrew W, Evans, Richard, Jumper, John, Kirkpatrick, James, et al. (2020) 'Improved protein structure prediction using potentials from deep learning'. Nature, 577(7792), pp. 706-710.

5. Amelia, Fitri (2013) 'Modeling struktur protein vaksin H5N1 HA BTB menggunakan I-Tasser'. Jurnal Sainstek, 7(01).

6. Mutiah, Roihatul, Widyawaruyanti, Aty and Sukardiman, Sukardiman (2018) 'Calotropis gigantea leaf extract increases the efficacy of 5-fluorouracil and decreases the efficacy of doxorubicin in Widr colon cancer cell culture'. Journal of Applied Pharmaceutical Science, 8(04), pp. 51-56.

7. Lang, Jianshe, Vera, Daniel, Cheng, Yichen and Tang, Hengli (2016) 'Modeling dengue virus-hepatic cell interactions using human pluripotent stem cell-derived hepatocyte-like cells'. Stem cell reports, 7(3), pp. 341-354.

8. Takata, Kei-ichi, Reh, Shelley, Yousefzadeh, Matthew J, Zelazowski, Maciej J, et al. (2017) 'Analysis of DNA polymerase $v$ function in meiotic recombination, immunoglobulin class-switching, and DNA damage tolerance'. PLoS genetics, 13(6), p. e1006818.

9. Wardhana, Akhmad Kusuma (2020) 'Should be halal? is there any correlation between halal and vaccine? bibliography study in SCOPUS indexed academic paper'. Journal of Halal Product and Research (JHPR), 3(2), pp. 80-87.
10. Kim, GyungRyul, Alam, Md Jobaidul, Kim, Hyun-Woo and Andriyono, Sapto (2019) 'Complete mitochondrial genome of green shrimp, Chlorotocus crassicornis (Crustacea: Decapoda: Pandalidae) in Korean water'. Mitochondrial DNA Part B, 4(2), pp. 2206-2207.

11. Berman, Helen, Henrick, Kim, Nakamura, Haruki and Markley, John $L$ (2007) 'The worldwide Protein Data Bank (wwPDB): ensuring a single, uniform archive of PDB data'. Nucleic acids research, 35(suppl_1), pp. D301-D303.

12. Wardhana, Akhmad Kusuma (2020) 'Information search trends about sharia: a comparation study between business-industry genre with book-literature genre'. Journal of Halal Product and Research, 3(1), pp. 35-42.

13. Adebayo, K O, Aderinboye, R Y, Sanwo, K A, Oyewusi, I K and Isah, O A (2019) 'Growth performance and fecal worm egg count of West African dwarf goats fed diets containing varying levels of Ocimum gratissimum (Scent leaf)'. Bone, 17(17.0), pp. 10-17.

14. Mehta, Neil A, Murray, Vanessa J, Xu, Chenbiao, Levin, Deborah A and Minton, Timothy K (2018) 'Nonreactive scattering of N2 from layered graphene using molecular beam experiments and molecular dynamics'. The Journal of Physical Chemistry C, 122(18), pp. 98599874.

15. Shentu, Zujun, Al Hasan, Mohammad, Bystroff, Christopher and Zaki, Mohammed J (2008) 'Context shapes: Efficient complementary shape matching for protein-protein docking'. Proteins: Structure, Function, and Bioinformatics, 70(3), pp. 1056-1073.

16. Motta, Mario and Zhang, Shiwei (2018) 'Ab initio computations of molecular systems by the auxiliary-field quantum Monte Carlo method'. Wiley Interdisciplinary Reviews: Computational Molecular Science, 8(5), p. e1364.

17. Bordoli, Lorenza, Kiefer, Florian, Arnold, Konstantin, Benkert, Pascal, et al. (2009) 'Protein structure homology modeling using SWISSMODEL workspace'. Nature protocols, 4(1), p. 1.

18. Garcia-Saez, Isabel, Menoni, Hervé, Boopathi, Ramachandran Shukla, Manu S, et al. (2018) 'Structure of an H1-bound 6-nucleosome array reveals an untwisted two-start chromatin fiber conformation'. Molecular cell, 72(5), pp. 902-915.

19. Chiang, Han-Sun, Wang, Ya-Yun, Lin, Ying-Hung and Wu, Yi-No (2019) 'The role of SLC9A3 in Taiwanese patients with congenital bilateral absence of vas deferens (CBAVD)'. Journal of the Formosan Medical Association, 118(12), pp. 1576-1583. 